\title{
HEAVY METALS IN AYURVEDIC MEDICINES
}

\author{
Dr. D. SURESH KUMAR Ph.D. \\ Cymbio Pharma Pvt Ltd, Yeswanthpur, Bangalore - 560 022, India
}

\begin{abstract}
A yurveda is the traditional medicine of India that has been practiced since ancient times. According to the modest estimates made by European scholars, it has a track record of 20 1 centuries. However, protagonists of the system claim that it is more ancient. Ayurveda texts give clear instructions on the type of land from which medicinal plants are to be collected. For example, Carakā Samhita states that herbs should not be collected from polluted places, burial grounds, pits, parks, ant hills and salty terrain. Similar views are expressed in Aștāngahrdaya and Śārngadhara Samhita. It is quite logical to presume that adherence to these conditions must have helped in maintaining quality of herbs collected in those days. Manufacture of ayurvedic medicines has become an industrial activity in modern times. This has given rise to a brisk trade in medicinal herbs. Consequently, herbs are collected indiscriminately from all kinds of environment and this raises the problem of chemical contamination.
\end{abstract}

In 2004 Saper et al published their report on the heavy metal content of ayurvedic medicines, based on the heavy metal analysis of Mahāsudarśana Cürna, Mahalakshmi Vilas Ras with Gold, Navratna Rasa and Mahayograj Guggulu with Silver and Makardhwaj.. This was followed by several reports of heavy metal contamination in ayurvedic medicines. Almost all these studies were based on information obtained from ayurvedic medicines prepared from calcined metals and inorganic substances. Not much information is available on the content of heavy metals in traditional ayurvedic medicines prepared exclusively from herbs.

To fill this gap, a small group of researchers in the Ayurveda consortium CARE Keralam Ltd., Chalakkudi, Kerala recently carried out an extensive study on the heavy metal content of ayurvedic medicines in traditional dosage forms (Aryavaidyan 28 (2), 101-111). The content of lead, arsenic, cadmium and mercury in 126 ayurvedic medicines manufactured by 32 companies was analyzed using Inductively Coupled Plasma-Mass Spectrometer (ICP-MS). The content of these heavy metals in 34 common ayurvedic herbs was also estimated. 
All the ayurvedic medicines and herbs studied contained lead, arsenic, cadmium and mercury in quantities below the limits set by Government of India. This study is hoped to counter the allegation that all ayurvedic medicines contain alarming levels of heavy metals and that they are hazardous to health.

The branch of Ayurveda that deals with calcined minerals and metals is known as rasaśāstra (science of mercury). It has a large literature dating from the end of the first millennium A.D. The tradition of rasaśāstra shares some features with alchemy prevalent in medieval Europe.

Ayurvedic bhasmas are recommended at very low doses, often in divided doses, and for a specific period of time. This suggests that the ancient authors might have been aware of the dangers of improper administration. Mainstream Ayurveda treatises like Suśruta Samhita, Caraka Samhita, Aștāñgasamgraha and Aștāingahṛdaya do not deal with calcined minerals and metals. It is argued that mercury, arsenic and lead lose their toxic nature when subjected to the lengthy and strenuous ayurvedic methods of detoxification and calcining. However, no scientific evidence is available in support of this claim. Therefore, there is an urgent need to study the rationale of rasaśāstra and the toxicology of rasaśāstra preparations. 